\title{
Engineering to Enhance STEM Integration Efforts
}

\section{Dr. Tamara J Moore, Purdue University}

Tamara J. Moore, Ph.D. is an Associate Professor of Engineering Education at Purdue University. Dr. Moore's research is centered on the integration of STEM concepts in K-12 and higher education mathematics, science, and engineering classrooms in order to help students make connections among the STEM disciplines and achieve deep understanding. Her research agenda focuses on defining STEM integration and investigating its power for student learning. She is creating and testing innovative, interdisciplinary curricular approaches that engage students in developing models of real world problems and their solutions. Her research also involves working with educators to shift their expectations and instructional practice to facilitate effective STEM integration.Tamara is the recipient of a 2012 Presidential Early Career Award for Scientists and Engineers (PECASE) for her work on STEM integration with underrepresented minority and underprivileged urban K-12 students.

\section{Kristina Maruyama Tank, University of Minnesota, Twin Cities Mr. Aran W Glancy, University of Minnesota, Twin Cities}

Aran W. Glancy is a Ph.D. Candidate in STEM Education with an emphasis in Mathematics Education at the University of Minnesota. He is a former high school mathematics and physics teacher, and he has experience both using and teaching a variety of educational technologies. His research interests include mathematical modeling, computational thinking, and STEM integration. Specifically, he is interested in the ways in which integrating engineering or computer science into mathematics and science classes can support and enhance learning within and across the STEM disciplines.

\section{Emilie A Siverling, Purdue University}

Emilie A. Siverling is a Ph.D. Student in Engineering Education at Purdue University. She received a B.S. in Materials Science and Engineering from the University of Wisconsin-Madison, and she is a former high school chemistry and physics teacher. Her research interests are in K-12 STEM integration, primarily using engineering design to support secondary science curricula and instruction.

\section{Mrs. Corey A Mathis, Purdue University}

Corey A. Mathis earned her B.S. in biology and her M.E.D. in secondary education from Northern Arizona University. Prior to returning to school to obtain a $\mathrm{PhD}$ in engineering education at Purdue University, Corey spent nine years as a 7-12 grade Arizona science teacher. While at Purdue she has developed a course for Engineering Technology Pathways in addition to bring statistic to science classrooms though teacher outreach programs. 


\title{
Engineering to Enhance STEM Integration Efforts
}

\begin{abstract}
Currently, there is a movement in $\mathrm{K}-12$ education to include engineering academic standards in the science curriculum. The Next Generation Science Standards, which include engineering design learning ideas, are starting to be adopted by states. This research project builds on the STEM Integration research paradigm, defined as the merging of the disciplines of STEM. There are two main types of STEM integration: content integration and context integration. Content integration focuses on the merging of the content fields into a single curriculum in order to highlight "big ideas" from multiple content areas, whereas context integration focuses on the content of one discipline and uses contexts from others to make the content more relevant.
\end{abstract}

This paper reports the current research on an NSF Early Faculty CAREER Development project that advances pedagogical understanding about how to teach STEM content in an interdisciplinary manner in K-12 classrooms. It posits the theoretical models of context and content integration across STEM and models of student learning in these context-rich interdisciplinary problem spaces. By researching the implementation of K-12 engineering standards, this project adds to the theoretical basis for student learning in STEM integration environments.

\section{Introduction}

Integration of Science, Technology, Engineering, and Mathematics (STEM) in K-12 education is gaining attention. STEM integration has potential to increase student interest in STEM subjects and, therefore, the pathways to STEM fields. The Next Generation Science Standards ${ }^{1}$, as well as state science standards such as Massachusetts ${ }^{2}$ and Minnesota ${ }^{3}$, have increased this attention, as they require engineering to be taught along with science throughout the K-12 curriculum.

Along with the need to address these new standards, there is a need for a robust understanding of how teachers are implementing engineering in their classrooms. This research documents the curricula developed by teachers of science involved in a large-scale teacher professional development focused on STEM integration. Because the schools involved in the teacher professional development include high needs schools in an urban area, this research also explores the proposed learning outcomes of underrepresented populations when presented with a STEM integration curricular unit. The inclusion of teacher professional development in the project informs teacher preparation in STEM integration and provides necessary data for making informed decisions about the direction for STEM curricula in the teaching and learning of STEM content.

In order to describe the curricular units created by the teachers in this professional development, this paper will present the STEM integration framework and approach that was implemented in the professional development. This will be followed by the structure and format of the teacher professional development used to help teachers learn to translate this STEM integration framework into practice through curriculum writing and pedagogy. Finally, the paper will provide cases of curricular modules developed through this professional development in order to address the research question: 
How are teachers using STEM content integration and context integration to address engineering standards in curricular modules written to teach science, data analysis, and measurement?

\section{STEM Integration Framework}

This paper applies the STEM integration research paradigm ${ }^{4}$ to understand how teachers apply STEM integration into classroom curricula. Here, STEM integration is defined to be the blending of science, technology, engineering, and mathematics content and context into one learning environment for the purpose of (1) deepening student understanding of each discipline by contextualizing concepts, (2) broadening student understanding of STEM disciplines through exposure to socially and culturally relevant STEM contexts, and (3) increasing interest in STEM disciplines to broaden the pipeline of students entering the STEM fields ${ }^{5}$.

High quality STEM integration has been identified to have the following six characteristics ${ }^{4}$. First, the context must be both motivating and engaging so students develop personal connections to the activities ${ }^{6-8}$. Second, students must actively engage in an engineering design challenge that develops students' problem-solving, creativity, and higher-order thinking skills ${ }^{9}$. Third, lesson activities should provide opportunities for students to learn from failure and redesign ${ }^{10}$. Fourth, the main objectives of the lesson must include meaningful mathematics and/or science content ${ }^{11-13}$, which are enhanced by the engineering design activities. In addition, lessons that incorporate non-STEM content, such as reading or social studies, are highly encouraged. Fifth, to develop deep understanding of mathematical and scientific knowledge, teachers should implement student-centered pedagogies ${ }^{14-16}$. Finally, the lessons must incorporate teamwork ${ }^{7,14,17}$ and communication ${ }^{17-20}$.

There are two ways STEM integration can be implemented into classroom instruction: content integration and context integration. Content integration places emphasis on merging subject matter from multiple disciplines to create a curriculum that addresses content ideas from a combination of disciplines concurrently. For example, a life science teacher might teach a unit that focuses on developing a coating to reduce frictional resistance of hip replacement joints to improve the lifespan of the product. A stronger coating would essentially increase the lifespan of hip replacements beyond the 10 years, reducing recipients' need for additional replacements. This would allow the integration of content from multiple disciplines, including biology, biomedical engineering, chemistry, physics, and mathematics. STEM disciplines blended into one curriculum that address a socially relevant issue, such as improving the quality of life, allows teachers to teach materials from multiple fields while stressing how each is required to solve a problem. On the other hand, context integration accents one discipline while using a second to frame the lesson for the purpose of creating meaning, relevance, and motivation. For example, a mathematics teacher may ask students to participate in a problem solving activity where the context is a company that is examining the reliability of tires to increase the safety of a vehicle. The context is engineering, but the unit focus is statistics, specifically Chi-square testing. Teachers can use either approach for STEM integration into their courses or blend them ${ }^{5}$.

\section{Method}

This paper utilizes a multiple-case study design ${ }^{21,22}$ that examines five curricular modules developed by teams of teachers involved in an intensive summer and school-year professional 
development institute in order to fully understand teachers' implementation strategies as they work to address engineering standards in the K-12 classroom. According to Creswell ${ }^{22}$, the purpose of a case study is to explore a program (or other entity) in depth. "The cases are bounded by time and activity, and researchers collect detailed information using a variety of data collection procedures over a sustained period of time" (p. 15). The overall design is a multi-case case study that examines five engineering design curricula written by 10 elementary and middle school teachers. A closer look at the curricula will provide a better understanding of how teachers integrate STEM into their classroom instruction.

\section{Teacher Professional Development}

The teachers participated in summer professional development and curriculum writing workshops, paired with coaching, for the purpose of helping teams of teachers to design and implement engineering-design curricular modules focused on science concepts, meaningful data analysis, and measurement. Each of the teachers attended a three-week summer institute. The first week of the institute was dedicated to engineering design, measurement, and data analysis pedagogies. Teachers were exposed to an engineering design process and completed a variety of engineering activities to improve their understanding of engineering and engineering integration into science classrooms. Teachers also learned how engineering, measurement, and data analysis are applied in science. Particularly, teachers engaged in activities where they improved their abilities and skills to teach mathematics and engineering in science classes. During the second week, the summer institute involved in-depth exploration of science content in one of the "big ideas" of science included in grades 4-8. Teachers chose one of the three science content domains (earth science, physical science, or life science) as their content focus based on standards at their grade level. Activities were designed to improve teachers' content knowledge and develop pedagogical knowledge and confidence in using inquiry and design-based strategies to teach science content. The teachers featured in this case study focused on one of two areas: (1) landforms and plate tectonics or (2) heat transfer and the particulate nature of matter. Finally, teachers explored different approaches to integrate engineering into their science teaching. In the third week, teachers worked collaboratively in teams of 2-4 teachers, with support from their assigned STEM coaches, to design STEM integration curricula to be implemented in their classrooms. Following week three, teachers piloted their curricula in a STEM summer camp, allowing them to reflect on and modify their curricula prior to implementation in their own classrooms. The STEM summer camps included students from grades 4-8, and teachers were able to pilot their curricula with a group of approximately eight students for two 2.5 hour summer camp sessions. During the fall, the teachers made changes to their curricula based on their pilot experiences, so they were ready to implement the curricula in their classrooms.

\section{Participants}

Our sample includes 10 participants who developed 5 curricular units during the summer institute. The participants are affiliated with 8 schools within 2 large districts in the Midwest. Table 1 provides information about the participants and their schools. Only units that were implemented into the classroom by then end of the fall semester were included in this study. These 5 units were assessed using the frameworks of STEM context and content integration to determine how the teachers implemented the material into their classroom. 
Table 1. Demographics of the teams of teachers who created the 5 case curricula and their school/district affiliation.

\begin{tabular}{|l|c|c|c|c|}
\hline \multicolumn{1}{|c|}{ Module } & Teachers & $\begin{array}{c}\text { Grade } \\
\text { Level }\end{array}$ & School & District \\
\hline \multirow{4}{*}{$\begin{array}{l}\text { Human Impact on Mississippi River } \\
\text { Recreational Area Design }\end{array}$} & Hannah & $4 \& 5$ & International Magnet & $\begin{array}{c}\text { Urban/High } \\
\text { Diversity }\end{array}$ \\
\cline { 2 - 5 } & April & $4 \& 5$ & Earl Elementary & $\begin{array}{c}\text { Urban/High } \\
\text { Diversity }\end{array}$ \\
\hline \multirow{4}{*}{ Solar Ovens } & Denny & $4 \& 5$ & $\begin{array}{c}\text { Gifted \& Talented } \\
\text { Magnet }\end{array}$ & $\begin{array}{c}\text { Urban/High } \\
\text { Diversity }\end{array}$ \\
\cline { 2 - 5 } & Kara & 6 & Loring MS & $\begin{array}{c}\text { Suburban/ Low } \\
\text { Diversity }\end{array}$ \\
\cline { 2 - 5 } & Sona & 6 & Technology Magnet & $\begin{array}{c}\text { Urban/High } \\
\text { Diversity }\end{array}$ \\
\cline { 2 - 5 } & Jacob & $7 \& 8$ & Buford MS & $\begin{array}{c}\text { Urban/High } \\
\text { Diversity }\end{array}$ \\
\hline Rocket Powered Delivery SySTEM & Jerri & 4 & Gifted \& Talented & $\begin{array}{c}\text { Urban/High } \\
\text { Diversity }\end{array}$ \\
\cline { 2 - 5 } & Reno & $4 \& 5$ & Montessori School & $\begin{array}{c}\text { Urban/High } \\
\text { Diversity }\end{array}$ \\
\cline { 2 - 5 } Ecuadorian Fisherman (Year 1 and Year 2) & Sienna & $7 \& 8$ & Mohan Jr. High & $\begin{array}{c}\text { Urban/High } \\
\text { Diversity }\end{array}$ \\
\cline { 2 - 5 } & Kona & $7 \& 8$ & Mohan Jr. High & $\begin{array}{c}\text { Urban/High } \\
\text { Diversity }\end{array}$ \\
\hline
\end{tabular}

\section{Cases}

To report the findings from this research, each of the 5 curricular module "cases" will be presented. This will include a short description of each curricular module followed by a description of how each module used content and/or context integration. Finally, a cross case analysis of the findings will be discussed.

\section{Human Impact on Mississippi River Recreational Area Design}

This 7-lesson curricular module aimed at 5 th grade students invites students to design a way to preserve the land in a park from human impacts related to landforms, in particular erosion. In this unit, students receive a memo from Ms. Harriet, Mississippi River Fossil Foundation local president. Ms. Harriet has outlined the criteria for an outdoor functional area near the Mississippi River to be designed by local community members. The land needs to promote outdoor recreational areas, such as fishing piers and overnight camping, in order to increase usage by local residents and focus on preserving the park's natural attractions. It is important to Ms. Harriet to keep the Mississippi River's natural features preserved for future park visitors. Ms. Harriet has a grant of up to $\$ 600,000$ that design engineers will use as their budget for the preservation and utilization of the local area. Ms. Harriet has asked students to create a land use proposal that will convince Ms. Harriet, her committee board, and other potential investors to use the student teams' preservation designs as the Mississippi River's newest park highlights.

This unit uses context integration for each of the 7 lessons to build to the whole unit, which overall is content integration. Table 2 provides a description of each lesson and how content is 
presented. There are several instances in this curriculum where simple changes in how the curriculum was written could make this curriculum have stronger connections and, therefore, lend more to content integration.

Table 2. Human Impact on Mississippi River Recreational Area Design lesson descriptions and analysis of content/context integration.

\begin{tabular}{|c|c|c|}
\hline Lesson & Lesson Description & Content/Context Integration \\
\hline $\begin{array}{l}1 \text { - Initial } \\
\text { Design }\end{array}$ & $\begin{array}{l}\text { Students design, without any pre-teaching, on a given map located } \\
\text { along the Mississippi River. They are given an option list for } \\
\text { choices (e.g., hiking trails, biking trails) of what they would like to } \\
\text { place in the outdoor area. At the closing of the lesson, the students } \\
\text { learn that the choices they have made negatively impact the natural } \\
\text { system. }\end{array}$ & $\begin{array}{l}\text { Context: } \\
\text { Primary - Engr design } \\
\text { Supporting - Math (budget } \\
\text { constraints), Sci } \\
\text { (test/evaluate designs on } \\
\text { how they impact natural } \\
\text { system) }\end{array}$ \\
\hline $\begin{array}{l}2 \text { - } \\
\text { Investigating } \\
\text { Permeability of } \\
\text { Soil }\end{array}$ & $\begin{array}{l}\text { Students test soil samples found near the Mississippi River and } \\
\text { surrounding area for permeability (i.e., measure the time each } \\
\text { sample takes to drain and then graph the data). At the end, the } \\
\text { whole class makes a list of information learned that can apply to } \\
\text { their re-designs. }\end{array}$ & $\begin{array}{l}\text { Context and Content: } \\
\text { Primary - Math/Sci (collect } \\
\text { and graph data) (content) } \\
\text { Supporting - Engr (apply } \\
\text { info to redesigns) (context) }\end{array}$ \\
\hline $\begin{array}{l}3 \text { - Statistics of } \\
\text { Rainfall }\end{array}$ & $\begin{array}{l}\text { Students learn about data analysis to calculate average rainfall (of } \\
\text { past } 5 \text { years in St. Paul, MN) to inform where Earth materials } \\
\text { should be located in the park. }\end{array}$ & $\begin{array}{l}\text { Context: } \\
\text { Primary - Math (data } \\
\text { analysis of rainfall) } \\
\text { Supporting - Engr (apply to } \\
\text { redesign) }\end{array}$ \\
\hline 4 - Runoff Test & $\begin{array}{l}\text { Students learn science vocabulary "runoff" and "contaminants." } \\
\text { They then set up run-off bottles (for a } 5 \text { day experiment) to } \\
\text { observe fertilizer (i.e., Kool-Aid) runoff. }\end{array}$ & $\begin{array}{l}\text { Context: } \\
\text { Primary - Sci (how humans } \\
\text { impact natural systems), } \\
\text { Sci/Math (measurements) } \\
\text { Secondary - Engr (apply to } \\
\text { redesign) }\end{array}$ \\
\hline $\begin{array}{l}5 \text { - Human } \\
\text { Impact around } \\
\text { the World }\end{array}$ & $\begin{array}{l}\text { Students work in groups to research (i.e., watch time-lapse video } \\
\text { and read articles) and evaluate current issues due to human impact } \\
\text { around the world. Key vocabulary for this lesson are human } \\
\text { impact, deforestation, irrigation, global warming, and sediment. } \\
\text { Groups then share information with the whole class. Students use } \\
\text { these findings to influence their re-designs of the park. }\end{array}$ & $\begin{array}{l}\text { Context: } \\
\text { Primary - Sci (compare } \\
\text { how humans impact natural } \\
\text { systems) } \\
\text { Secondary - Engr (apply to } \\
\text { redesign) }\end{array}$ \\
\hline $\begin{array}{l}6 \text { - Other } \\
\text { Clients }\end{array}$ & $\begin{array}{l}\text { Students learn about other investors interested in the design } \\
\text { project. Students work to represent the original client, as well as } \\
\text { other investors, in final redesign of their Mississippi Recreational } \\
\text { Park. }\end{array}$ & $\begin{array}{l}\text { Context: } \\
\text { Primary - Engr (create list } \\
\text { of desired features for } \\
\text { redesign, learn to address } \\
\text { multiple client interests) } \\
\text { Secondary - Sci (review } \\
\text { human impact } \\
\text { considerations) }\end{array}$ \\
\hline 7 - Redesign & $\begin{array}{l}\text { Students redesign using: science knowledge learned about human } \\
\text { impact on natural systems, including key vocabulary; client(s) }\end{array}$ & $\begin{array}{l}\text { Context: } \\
\text { Primary - Engr (redesign }\end{array}$ \\
\hline
\end{tabular}




\begin{tabular}{|l|l|l|}
\hline & $\begin{array}{l}\text { desired features; and budget. They are given an option list for } \\
\text { choices of what they would like to place in the outdoor area. At the } \\
\text { closing of the lesson, the students share their design with the } \\
\text { client, as well as a planned persuasive presentation to influence the } \\
\text { client to select their recreational design. }\end{array}$ & $\begin{array}{l}\text { park considering client } \\
\text { needs and budget) } \\
\text { Secondary - Sci (use } \\
\text { learned info on human } \\
\text { impact in redesign) }\end{array}$ \\
\hline
\end{tabular}

\section{Solar Ovens}

In this 7-lesson unit, aimed at $6^{\text {th }}$ grade, using a context of children dying all over the world due to unsanitary water and food, students are asked to design and construct a low cost solar oven that will cook meat to an internal temperature of $165^{\circ} \mathrm{F}$. The context suggests that poorer families in the tropics can use the solar ovens to cook and pasteurize drinking water when the sun is shining, thereby reducing firewood, charcoal, and dung fuel use; smoke inhalation; unsanitary water supplies; and global warming. Students learn about conduction, convection, and radiation through inquiry-based labs and guided instruction. Students also revisit previous topics learned, such as changes of energy forms, the electromagnetic spectrum, and reflection of light. In one activity, students use knowledge of science concepts to build a thermos. They design to make a solar oven as a final project.

This unit also primarily uses context integration for each lesson with an overall effect of content integration. Table 3 provides an overview of each lesson and how context or content integration is embedded. This unit provides the context in lesson one, but mostly ignores the engineering in lessons 2-4, only bringing it back to the forefront in the design phase. The unit does not provide an opportunity for the students to learn from failure or redesign.

Table 3. Solar Ovens lesson descriptions and analysis of content/context integration.

\begin{tabular}{|c|c|c|}
\hline Lesson & Description & $\begin{array}{l}\text { Content/Context } \\
\text { Integration }\end{array}$ \\
\hline $\begin{array}{l}1 \text { - Introduce } \\
\text { Design } \\
\text { Challenge, } \\
\text { Introduction to } \\
\text { Radiation }\end{array}$ & $\begin{array}{l}\text { The teacher briefly introduces the design challenge, which is to } \\
\text { design an inexpensive solar oven. The teacher then gives a } \\
\text { presentation to review thermal energy and temperature and to } \\
\text { introduce heat transfer, especially radiation. Students do an } \\
\text { activity where they discover how radiation (in this case a laser } \\
\text { light) can be reflected by bouncing it off of a mirror and then } \\
\text { graphing the data. Students learn that the incoming angle of } \\
\text { incidence and outgoing angle of reflection of the laser are the } \\
\text { same; this principle is the Law of Reflection. Finally, students } \\
\text { consider how their knowledge of radiation and light reflection } \\
\text { might influence their solar oven design. }\end{array}$ & $\begin{array}{l}\text { Content integration for Math } \\
\text { and science, context of } \\
\text { engineering: } \\
\text { Primary- Sci (introduce heat } \\
\text { transfer, especially radiation), } \\
\text { Math (investigate angles of } \\
\text { reflection) } \\
\text { Secondary - Engr (introduce } \\
\text { engr problem) }\end{array}$ \\
\hline $\begin{array}{l}2 \text { - How } \\
\text { Radiation } \\
\text { Transfers to Heat } \\
\text { Energy }\end{array}$ & $\begin{array}{l}\text { The teacher introduces the lab by asking students about } \\
\text { wearing white vs. black on a sunny day. Students then do an } \\
\text { activity where they measure the temperature increases of } \\
\text { different colors of felt, as well as a piece of aluminum foil, } \\
\text { every } 30 \text { seconds for } 3 \text { minutes when the samples are placed } \\
\text { near a heat source. Students make a line graph for each } \\
\text { sample. The teacher presents the visible light portion of the } \\
\text { electromagnetic spectrum, explaining that white objects reflect } \\
\text { all wavelengths and black objects absorb them all. Also, when } \\
\text { radiation is absorbed, thermal energy increases. Students fill in } \\
\text { their storyboards explaining, in terms of particle movement }\end{array}$ & $\begin{array}{l}\text { Context: } \\
\text { Primary - Sci (how different } \\
\text { colors affect the change of } \\
\text { energy from radiant to } \\
\text { thermal) } \\
\text { Supporting - Math (create } \\
\text { line graphs of each sample in } \\
\text { the lab) }\end{array}$ \\
\hline
\end{tabular}




\begin{tabular}{|c|c|c|}
\hline & $\begin{array}{l}\text { and thermal energy, the difference between white and black } \\
\text { objects when exposed to light waves. }\end{array}$ & \\
\hline $\begin{array}{l}3 \text { - Heat Transfer } \\
\text { by Convection }\end{array}$ & $\begin{array}{l}\text { The teacher introduces the concept of convection using a } \\
\text { burning candle demonstration (where students are to notice the } \\
\text { upward movement of the smoke) and then following with the } \\
\text { definition written into the students' graphic organizers. The } \\
\text { teacher then leads the cardboard house attic/basement activity, } \\
\text { where the temperature of air from the top and bottom of a } \\
\text { cardboard house are measured over time, first as heat lamps } \\
\text { beam on the roof and then after the lamps are shut off and the } \\
\text { house is flipped over. In groups, students create line graphs of } \\
\text { each thermometer in each situation and answer questions to } \\
\text { discover that less dense (hot) air moves upward and more } \\
\text { dense (cold) air moves downward. The teacher then explains } \\
\text { this in terms of convection and currents, vocabulary which } \\
\text { students record in their graphic organizers. }\end{array}$ & $\begin{array}{l}\text { Context: } \\
\text { Primary - Sci (convection and } \\
\text { currents) } \\
\text { Supporting - Math (create } \\
\text { line graphs of each } \\
\text { thermometer) }\end{array}$ \\
\hline $\begin{array}{l}4 \text { - Conduction } \\
\text { and Insulation }\end{array}$ & $\begin{array}{l}\text { The teacher introduces the concept of conduction by having } \\
\text { students feel a plastic tray and a metal tray to discover that } \\
\text { while the metal feels colder (because heat from the hand is } \\
\text { moving away faster), they are both at the same (ambient) } \\
\text { temperature. Student groups then each wrap a different } \\
\text { material around a milk carton of warm water and measure the } \\
\text { temperature change every } 10 \text { minutes, while graphing the data. } \\
\text { Student groups share results with the whole class to determine } \\
\text { which material is the best insulator. Finally, students add the } \\
\text { concepts of conduction, conductors, and insulators to their } \\
\text { storyboards. }\end{array}$ & $\begin{array}{l}\text { Context: } \\
\text { Primary - Sci (conduction, } \\
\text { conductor/insulator lab) } \\
\text { Secondary - Math (create line } \\
\text { graphs of each water cup) }\end{array}$ \\
\hline $\begin{array}{l}5 \text { - Thermal } \\
\text { Energy Transfer } \\
\text { Quiz, Solar Oven } \\
\text { Rubric }\end{array}$ & $\begin{array}{l}\text { Students review their storyboards with a partner. Students take } \\
\text { a short quiz on thermal energy background knowledge learned } \\
\text { thus far. Quizzes are graded immediately, and the teacher } \\
\text { clarifies misconceptions students still have. The teacher } \\
\text { presents the Solar Oven Engineering Design Project Rubric to } \\
\text { students so that they may start thinking about how their } \\
\text { background knowledge will influence their design. }\end{array}$ & $\begin{array}{l}\text { Context: } \\
\text { Primary - Sci (thermal energy } \\
\text { transfer knowledge quiz) } \\
\text { Secondary - Engr (consider } \\
\text { application of knowledge to } \\
\text { design) }\end{array}$ \\
\hline $\begin{array}{l}6 \text { - Design and } \\
\text { Construct Solar } \\
\text { Oven }\end{array}$ & $\begin{array}{l}\text { Students read through a letter explaining the need for solar } \\
\text { ovens in Afghanistan, which introduces them to the design } \\
\text { problem in a more detailed way than the day one introduction. } \\
\text { Student groups then design their solar ovens considering } \\
\text { material, size, and budget constraints and the thermal energy } \\
\text { transfer knowledge learned earlier. Once groups have drawn } \\
\text { their models, they construct their solar ovens. By the end of } \\
\text { the class, students have filled in the Identify the Problem, } \\
\text { Explore, Design, and Create boxes of their Engineering Design } \\
\text { Processes (EDPs). }\end{array}$ & $\begin{array}{l}\text { Context: } \\
\text { Primary - Engr (design and } \\
\text { construct solar ovens) } \\
\text { Secondary - Sci (apply info } \\
\text { of thermal energy transfer to } \\
\text { design), Math (work within } \\
\text { budget constraints) }\end{array}$ \\
\hline $\begin{array}{l}7 \text { - Testing the } \\
\text { Solar Oven }\end{array}$ & $\begin{array}{l}\text { Student groups place their solar cookers at the front of the } \\
\text { room. Students do a walking tour of the designs and discuss } \\
\text { which ones they think will record the highest temperature and } \\
\text { why. Solar ovens are tested, recording the temperature every } \\
\text { minute while a heat lamp shines on them. Groups record and } \\
\text { graph the temperature data. Afterwards, students fill in the Try } \\
\text { It Out and Make It Better boxes of their EPDs, as well as self- } \\
\text { scoring their designs on their rubrics. }\end{array}$ & $\begin{array}{l}\text { Context: } \\
\text { Primary - Engr (test and } \\
\text { evaluate solar ovens) } \\
\text { Secondary - Math (create line } \\
\text { graphs of temperature) }\end{array}$ \\
\hline
\end{tabular}




\section{Ecuadorian Fishermen}

This case is actually 2 cases. The two teachers who worked together to develop these units decided to do a theme across two years. In the first year, the $6^{\text {th }}$ grade students would work on one aspect of the engineering design challenge, and in the second year, the $7^{\text {th }}$ grade students would work on another.

A group that works with small businesses in Ecuador has discovered that some of the Ecuadorian fishermen need help. These fishermen take their small boats over to the Easternmost Galapagos Island (San Cristobal), which has many unusual and tasty fish. They need to bring ice with them in a cooler that will stay cold long enough to bring the fish back unspoiled (Year 1 - Ice/Freezer Problem). Once back to their fish markets in Ecuador, the fishermen need a small container to cook the fish in so they can be sold for the greatest profit (Year 2 - Cooker Container Problem). This curriculum is presented to take place over two years, but it can be taught as one large unit.

\section{Year 1 - Ice/Freezer Problem}

This unit uses context integration for almost every lesson, but overall, the unit has content integration as engineering, science, and mathematics objectives were all present. This unit keeps the engineering design context at the center of the students' attention throughout; however, the terms "engineering" or "engineering design" are not generally present. The lesson plans tend to use "challenge" or "problem" instead. Table 4 provides an overview of the lessons and how context and content integration are present in the lessons.

Table 4. Ecuadorian Fisherman - Year 1 Ice/Freezer Problem lesson descriptions and analysis of content/context integration.

\begin{tabular}{|l|l|l|}
\hline Lesson & Description & $\begin{array}{l}\text { Content/Context } \\
\text { Integration }\end{array}$ \\
\hline $\begin{array}{l}\text { 1 - Introduce } \\
\text { Initial Density } \\
\text { Lab }\end{array}$ & $\begin{array}{l}\text { Students read about the problem of fishermen needing a freezer } \\
\text { to keep fish cold. The teacher introduces a diagram that models } \\
\text { each steps of the engineering process. The teacher then } \\
\text { introduces the concepts of dissolving, diffusing, and density } \\
\text { with a demonstration of dissolving salt in water. Finally, the } \\
\text { students conduct an activity where they discover: 1) that mass } \\
\text { increases when salt is added to water but volume does not, and } \\
\text { 2) that hotter water dissolves salt faster. }\end{array}$ & $\begin{array}{l}\text { Context: } \\
\text { Primary - Sci (intro to density, } \\
\text { diffusing, dissolving; how } \\
\text { mass, volume and temperature } \\
\text { relate to dissolving) } \\
\text { Supporting - Engr (introduce } \\
\text { engr problem and process) }\end{array}$ \\
\hline $\begin{array}{l}\text { 2.1 - Introduce } \\
\text { Pensity, }\end{array}$ & $\begin{array}{l}\text { Students take notes on key vocabulary: diffusion, dissolving, } \\
\text { and density. The teacher reminds the students about the }\end{array}$ & $\begin{array}{l}\text { Content integration for Math } \\
\text { and science, context of } \\
\text { Melting Rate } \\
\text { Lab }\end{array}$ \\
$\begin{array}{l}\text { ice/freezer challenge. The teacher then introduces the density } \\
\text { formula (density = mass/volume) and models how to use it to } \\
\text { calculate density. Students break into groups and create certain } \\
\text { densities of salt water to be frozen for an activity the next day. } \\
\text { Students work on density practice problems in the remaining } \\
\text { class time. }\end{array}$ & $\begin{array}{l}\text { Primary - Sci (diffusing, } \\
\text { density, dissolving) and } \\
\text { Sci/Math (calculate density) } \\
\text { Supporting - Engr (remind } \\
\text { students of connection to } \\
\text { design challenge) }\end{array}$ \\
\hline $\begin{array}{l}\text { 2.2 - Testing } \\
\text { Melting Rate } \\
\text { through } \\
\text { Percent Mass }\end{array}$ & $\begin{array}{l}\text { The teacher explains what percent mass lost is and demonstrates } \\
\text { how to calculate it. Student groups then measure their three } \\
\text { samples (mass before, mass after 5 minutes of melting) and } \\
\text { calculate the percent mass lost for each and the average percent }\end{array}$ & $\begin{array}{l}\text { Context: } \\
\text { Primary - Sci (relate density to } \\
\text { melting rate) } \\
\text { Supporting - Math (calculating }\end{array}$ \\
\hline
\end{tabular}




\begin{tabular}{|c|c|c|}
\hline lost & $\begin{array}{l}\text { mass lost. Student groups share their data for each } \\
\text { concentration. Students create a line graph to show how density } \\
\text { changes the melting rate and relate this information to the } \\
\text { freezer problem. }\end{array}$ & $\begin{array}{l}\text { percent mass lost) } \\
\text { Engr (apply to freezer design) }\end{array}$ \\
\hline $\begin{array}{l}3-\text { Insulators } \\
\text { and Heat } \\
\text { Transfer }\end{array}$ & $\begin{array}{l}\text { The teacher reminds students of the design challenge. The } \\
\text { teacher leads a hot and cold touch demo, where students learn } \\
\text { that materials at the same temperature can feel different. } \\
\text { Students then do an insulator activity where they measure the } \\
\text { temperature of water bottles (or pop cans) that are wrapped in } \\
\text { various materials and share their results. The teacher leads a } \\
\text { class discussion about heat, temperature, and molecule } \\
\text { movement. Students copy the definitions of heat transfer, } \\
\text { temperature, heat, and heat insulator into their notebooks. } \\
\text { Students use an activity passing a beach ball around to } \\
\text { determine that closer molecules (like solids) conduct heat better } \\
\text { than farther ones (like gases). }\end{array}$ & $\begin{array}{l}\text { Context: } \\
\text { Primary - Sci (heat transfer and } \\
\text { insulators) } \\
\text { Secondary - Engr (apply to } \\
\text { freezer design challenge) }\end{array}$ \\
\hline $\begin{array}{l}4-\text { Design and } \\
\text { Build Freezers }\end{array}$ & $\begin{array}{l}\text { Students work in groups to design freezers, considering } \\
\text { knowledge of insulators and heat transfer, as well as budget and } \\
\text { volume constraints. After groups have a design drawn, they } \\
\text { purchase the materials and construct their design, while keeping } \\
\text { track of the total cost to stay within the budget. }\end{array}$ & $\begin{array}{l}\text { Context: } \\
\text { Primary - Engr (design and } \\
\text { construct freezer) } \\
\text { Secondary - Sci (apply info of } \\
\text { heat transfer to design), Math } \\
\text { (work within budget } \\
\text { constraints) }\end{array}$ \\
\hline $\begin{array}{l}5.1-\text { Test } \\
\text { Freezers }\end{array}$ & $\begin{array}{l}\text { Students test their freezers by measuring the mass of an ice } \\
\text { cube in the freezer before and after the freezer is placed in a } \\
\text { cooker box for } 15 \text { minutes. During the cooking time, groups } \\
\text { present their designs to the whole class. Students calculate the } \\
\text { overall and percent mass lost. Student groups share their results } \\
\text { with the class, and the whole class discusses the designs and } \\
\text { results. Students write how they want to change their design to } \\
\text { improve it. }\end{array}$ & $\begin{array}{l}\text { Context: } \\
\text { Primary - Engr (test and } \\
\text { evaluate design) } \\
\text { Secondary - Math (calculate } \\
\text { percent mass lost) }\end{array}$ \\
\hline $\begin{array}{l}5.2 \text { - Redesign } \\
\text { Freezers }\end{array}$ & $\begin{array}{l}\text { Student groups redesign their freezers, considering knowledge } \\
\text { of heat transfer and insulators, budget and volume constraints, } \\
\text { and results of initial testing. Students construct, test, and } \\
\text { evaluate their redesigned freezers, as well as present them to the } \\
\text { whole class. }\end{array}$ & $\begin{array}{l}\text { Context: } \\
\text { Primary - Engr (redesign, } \\
\text { construct, test, and evaluate } \\
\text { freezers) } \\
\text { Secondary - Sci (apply info of } \\
\text { heat transfer to design), Math } \\
\text { (work within budget, calculate } \\
\text { percent mass lost) }\end{array}$ \\
\hline $\begin{array}{l}6 \text { - Share } \\
\text { Results with } \\
\text { Client }\end{array}$ & $\begin{array}{l}\text { Students write letters to their clients, the fishermen, to } \\
\text { recommend the best ice salt/water mixture and freezer design to } \\
\text { use. Students include science knowledge in explanations of salt- } \\
\text { water ice mixture (density, diffusing, dissolving, and how } \\
\text { density affects melting rate) and heat transfer (heat transfer, } \\
\text { insulators, and how density affects heat transfer rate). They also } \\
\text { include an explanation of the engineering process, their design } \\
\text { and redesign, and results. }\end{array}$ & $\begin{array}{l}\text { Content: } \\
\text { Sci (explain density and } \\
\text { melting rate, explain insulation } \\
\text { and heat transfer) } \\
\text { Engr (explain design, redesign, } \\
\text { and process) }\end{array}$ \\
\hline
\end{tabular}

Year 2 - Cooker Container Problem

The second year of the Ecuadorian Fisherman unit focuses on students designing a container that will heat to a reliable temperature in order to cook the fish the fisherman bring in. This unit, more than the others, uses engineering design as the context throughout the unit. While it is primarily context integration for each lesson and then content integration overall, the unit keeps 
engineering at the forefront throughout the lessons. In Year 1, "engineering" and "design" are not generally used as vocabulary or reference words; however, in Year 2, they are a focal point of each lesson. Table 5 describes each lesson and provides the analysis with regards to context and content integration.

Table 5. Ecuadorian Fisherman - Year 2 Cooker Container Problem lesson descriptions and analysis of content/context integration.

\begin{tabular}{|c|c|c|}
\hline Lesson & Description & $\begin{array}{l}\text { Content/Context } \\
\text { Integration }\end{array}$ \\
\hline $\begin{array}{l}\text { 1.1 - Introduce } \\
\text { Problem, } \\
\text { Conduction Lab }\end{array}$ & $\begin{array}{l}\text { The teacher (re)introduces the problem faced by the Ecuadorian } \\
\text { fishermen. They have ice freezers, but now they need a small } \\
\text { portable cooking container to reach a reliable temperature so } \\
\text { they can cook their fish. Students then divide into groups and } \\
\text { do a two-part conduction activity. First, students feel wood, } \\
\text { Styrofoam } \AA \text {, and metal and note which surfaces feel warmer or } \\
\text { cooler. Second, students place ice on those surfaces and observe } \\
\text { on which surface the ice cubes melt the fastest. }\end{array}$ & $\begin{array}{l}\text { Context: } \\
\text { Primary - Sci (do } \\
\text { conduction lab) } \\
\text { Supporting - Engr } \\
\text { (introduce engr problem) }\end{array}$ \\
\hline $\begin{array}{l}1.2 \text { - More about } \\
\text { Conduction and } \\
\text { Heat Transfer }\end{array}$ & $\begin{array}{l}\text { Students discuss the results of the conduction lab from the } \\
\text { previous day in terms of insulators, conductors, and conduction. } \\
\text { (The words convection and radiation are also listed in the vocab } \\
\text { section of the lesson plan but not mentioned otherwise.) The } \\
\text { teacher introduces the concept of specific heat. Students handle } \\
\text { different materials available for making the cooker containers, } \\
\text { using thermometer strips to measure the temperature. }\end{array}$ & $\begin{array}{l}\text { Context: } \\
\text { Primary - Sci (conduction, } \\
\text { insulators, conductors, } \\
\text { specific heat) } \\
\text { Supporting - Engr } \\
\text { (materials in lab will be } \\
\text { material options for } \\
\text { design) }\end{array}$ \\
\hline $\begin{array}{l}2.1 \text { - Chemical and } \\
\text { Physical Changes, } \\
\text { Plan and Create } \\
\text { First Cooker } \\
\text { Container }\end{array}$ & $\begin{array}{l}\text { The teacher introduces the concept of a chemical change and } \\
\text { contrasts it with a physical change. The teacher reviews the } \\
\text { original goal of the cooker container challenge and the idea that } \\
\text { the chemical change of the fish cooking will be simulated by } \\
\text { test tubes of solution changing color as they are heated (i.e., } \\
\text { blue is undercooked, red is perfectly cooked, and black/brown } \\
\text { is overcooked). Students then design and create their first } \\
\text { cooker container that will allow the solution to heat to the } \\
\text { appropriate color, with consideration of constraints in cost and } \\
\text { size. }\end{array}$ & $\begin{array}{l}\text { Context: } \\
\text { Primary - Engr (design and } \\
\text { create first cooker oven) } \\
\text { Supporting - Sci (apply } \\
\text { knowledge of conductors } \\
\text { vs. insulators, learn about } \\
\text { chemical changes) }\end{array}$ \\
\hline $\begin{array}{l}2.2 \text { - Test Cooker } \\
\text { Containers }\end{array}$ & $\begin{array}{l}\text { Students test their cooker containers by adding a specific } \\
\text { volume of the solution to the test tubes within their containers } \\
\text { and leaving the containers in an oven for a set time. At the end } \\
\text { of the time, students record the color change, and the designs } \\
\text { are assessed based on color change and cost. As a whole class, } \\
\text { students share designs, data, and results. }\end{array}$ & $\begin{array}{l}\text { Context: } \\
\text { Primary - Engr (test and } \\
\text { evaluate cooker } \\
\text { containers) } \\
\text { Secondary - Sci (chemical } \\
\text { changes, heat transfer) }\end{array}$ \\
\hline $\begin{array}{l}2.3 \text { - Redesign and } \\
\text { Retest Cooker } \\
\text { Containers }\end{array}$ & $\begin{array}{l}\text { Students redesign and retest cooker containers based on } \\
\text { background science, cost and size constraints, and results of } \\
\text { initial design. During the retesting, students also measure the } \\
\text { mass of their solution, along with the final color. Again, they } \\
\text { share their designs, data, and results with the whole class, and } \\
\text { the class determines the best design. }\end{array}$ & $\begin{array}{l}\text { Context: } \\
\text { Primary - Engr (redesign } \\
\text { and reconstruct cooker } \\
\text { container) } \\
\text { Secondary - Sci (apply } \\
\text { info of heat transfer to } \\
\text { design), Math (work } \\
\text { within budget constraints) }\end{array}$ \\
\hline $\begin{array}{l}3 \text { - Create a } \\
\text { Cooking Chart, } \\
\text { Share Results with } \\
\text { Client }\end{array}$ & $\begin{array}{l}\text { Students use the mass and cooking score information, as well as } \\
\text { their knowledge of applying ratios, to calculate and create a } \\
\text { cooking time chart (vs. mass) for the client. The whole class } \\
\text { then discusses which design performed best and why, as well as }\end{array}$ & $\begin{array}{l}\text { Content: } \\
\text { Engr (explain design and } \\
\text { materials used for clients) } \\
\text { Sci (explain why materials }\end{array}$ \\
\hline
\end{tabular}




\begin{tabular}{|l|l|l|}
\hline & $\begin{array}{l}\text { how mass affected the cooking score. Finally, students write an } \\
\text { executive summary of their recommendations for cooker } \\
\text { container materials and design, as well as a cooking time chart, } \\
\text { for the client. }\end{array}$ & $\begin{array}{l}\text { are best in (calculate ratios to } \\
\text { make cooking chart) }\end{array}$ \\
\hline
\end{tabular}

\section{Rocket Powered Delivery SySTEM}

The Rocket Powered Delivery SySTEM unit is designed for $4^{\text {th }}$ grade students. In this unit, students are asked to develop a mixture for propulsion. The unit description follows:

Zip lines have become popular activities for adventurers. First used in China as a transportation method between mountain villages, zip lines can now be found at many vacation spots, including amusement parks. In this unit, students design a rocket-powered delivery sySTEM to move a single rider from a starting position to an ending point in Valley Fair, where customers have been complaining that it takes too long to walk from the exit for Power Tower to the line for Steel Venom. Valley Fair has already strung a 130 foot wire cable from a platform at one ride to a platform at the other. Typically, zip lines use gravity to move riders from the start to the finish of the zip line, but Valley Fair has installed a horizontal line, so students need to come up with a rocket-powered delivery sySTEM. A rocket-powered zip line will not only make lines more efficient, but it will also be a great marketing tool for Valley Fair!

This unit is very strong on the science, but it is very weak in the engineering. The unit begins and ends with reference to engineering, but focuses on science in the middle lessons. The engineering design in the final lessons is also weak, as it does not seem that students have the opportunity to arrive at different answers. Table 6 provides an overview of the lessons and how context and content integration are addressed. This unit was strong on science and weak in engineering and mathematics. While the context could have lent itself to very interesting engineering, the closedended nature of the activity does not allow students to think like engineers.

Table 6. Rocket Powered Delivery SySTEM lesson descriptions and analysis of content/context integration.

\begin{tabular}{|c|c|c|}
\hline Lesson & Description & $\begin{array}{l}\text { Content/Context } \\
\text { Integration }\end{array}$ \\
\hline $\begin{array}{l}1 \text { - Introduce Zip } \\
\text { Lines and Design } \\
\text { Challenge }\end{array}$ & $\begin{array}{l}\text { Students are introduced to what a zip line is though pictures, } \\
\text { video clips, and/or discussion. Student groups build a simple } \\
\text { zip line, a binder clip on an angled string, to discover how a } \\
\text { rider moves from the top of the line to the bottom (gravity). } \\
\text { Students then fill out a storyboard with this information: what a } \\
\text { zip line is and how it works. The teacher then introduces the } \\
\text { problem that the amusement park is having with their zip line } \\
\text { (that they want to build a flat zip line to shuttle riders around } \\
\text { the park), and the students write down that problem in their } \\
\text { storyboards. }\end{array}$ & $\begin{array}{l}\text { Context: } \\
\text { Primary - Sci (what zip lines } \\
\text { are and how they work) } \\
\text { Supporting - Engr (introduce } \\
\text { design challenge) }\end{array}$ \\
\hline $\begin{array}{l}2 \text { - Molecular } \\
\text { Spacing of Solids, } \\
\text { Liquids, and } \\
\text { Gases }\end{array}$ & $\begin{array}{l}\text { Student groups review what they already know about solids, } \\
\text { liquids, and gases, writing down their definitions and a few } \\
\text { examples. The teacher leads a whole class discussion to refine } \\
\text { these responses and write them on a poster. The teacher then } \\
\text { presents two books that show how molecules of solids, liquids, } \\
\text { and gases are different. Student groups use marshmallows and } \\
\text { toothpicks to build models of each state of matter and then } \\
\text { explain their models to the rest of the class. This information }\end{array}$ & $\begin{array}{l}\text { Context: } \\
\text { Primary - Sci (molecule } \\
\text { spacing in states of matter) }\end{array}$ \\
\hline
\end{tabular}




\begin{tabular}{|c|c|c|}
\hline & $\begin{array}{l}\text { about molecule spacing is added to the definitions on the } \\
\text { poster. }\end{array}$ & \\
\hline $\begin{array}{l}3 \text { - Conservation } \\
\text { of Mass, Why } \\
\text { Balloons Expand }\end{array}$ & $\begin{array}{l}\text { The teacher leads a whole class discussion of how something } \\
\text { can change from one state of matter into another and } \\
\text { introduces the idea that a chemical reaction can also cause this. } \\
\text { The student groups then mix Alka-Seltzer and water in a } \\
\text { beaker sealed with a balloon to discover that the solid and } \\
\text { liquid mix together to make a gas and expand the balloon. The } \\
\text { students then repeat the experiment while measuring the mass } \\
\text { of the system before and after mixing to discover that the mass } \\
\text { stays the same. The teacher leads a discussion about how, } \\
\text { though the mass didn't change, the solid turning into a gas } \\
\text { made the balloon expand because gases have greater molecular } \\
\text { spacing than solids. Students fill out this information on their } \\
\text { storyboards. }\end{array}$ & $\begin{array}{l}\text { Context: } \\
\text { Primary - Sci (mass is } \\
\text { conserved, but volume can } \\
\text { change) }\end{array}$ \\
\hline $\begin{array}{l}4.1 \text { - Force of } \\
\text { Alka-Seltzer and } \\
\text { Water Mixture }\end{array}$ & $\begin{array}{l}\text { The teacher leads a whole class discussion about how } \\
\text { expansion of matter is used in rockets, as shown with a video, } \\
\text { and relates this back to the amusement park problem. The } \\
\text { teacher shows students that when Alka-Seltzer and water are } \\
\text { placed in a film canister flipped upside down, it bursts upward. } \\
\text { Student groups then test the amount of force generated (either } \\
\text { by height reached or using force sensors) by these film canister } \\
\text { rockets by keeping the Alka-Seltzer constant and each group } \\
\text { using a different amount of water. Each group performs four } \\
\text { trials of their assigned mixture to find the average force. } \\
\text { Students share their data with the whole class, which should } \\
\text { discover that less water generates more force, since it allows } \\
\text { more room for gases to expand and build up pressure before } \\
\text { bursting. }\end{array}$ & $\begin{array}{l}\text { Context: } \\
\text { Primary - Sci (conducting a } \\
\text { controlled experiment, less } \\
\text { water generates more force) } \\
\text { Supporting - Engr (reminder } \\
\text { of problem in introduction), } \\
\text { Math (finding average, } \\
\text { making a table) }\end{array}$ \\
\hline $\begin{array}{l}4.2 \text { - Zip Line } \\
\text { Testing }\end{array}$ & $\begin{array}{l}\text { Student groups make film canister rockets again, but this time } \\
\text { the rockets move across a taut fishing line. Each group tests } \\
\text { their mixture of Alka-Seltzer and water three times to find the } \\
\text { average horizontal distance their rocket propels. The whole } \\
\text { class then determines which mixture makes the rocket move } \\
\text { the correct distance and stop in the landing zone. Finally, } \\
\text { students write a letter to the amusement park to explain the } \\
\text { correct mixture, the science behind it (expanding matter can be } \\
\text { turned into work), and how they came to that conclusion } \\
\text { (explain testing). }\end{array}$ & $\begin{array}{l}\text { Content: } \\
\text { Primary - Sci (conducting a } \\
\text { controlled experiment to } \\
\text { determine mixture for correct } \\
\text { distance moved) } \\
\text { Supporting - Engr (writing a } \\
\text { letter to client explaining } \\
\text { best mixture), Math (finding } \\
\text { average, making a table) }\end{array}$ \\
\hline
\end{tabular}

\section{Cross Case Analysis}

When looking across the five cases, the vast majority of lessons were context-integrated, though the units considered as a whole were generally content-integrated. The layout of the curricular units was similar in many of the cases, with the first day serving as an introduction to the engineering problem before introducing the necessary science background and ending with an engineering project. Even though there was a similarity in the overall layout, some of the units showed evidence of connecting the science background to the design challenge, while other units didn't explicitly mention it in the unit plans. The Mississippi River Park, Fishermen Freezer, and Fishermen Cooker Container units made it a point to intentionally connect the science that the students were learning with the engineering problem and subsequent engineering design challenge. The Solar Oven and Rocket Powered Zip Line units presented science that was related 
to the engineering design challenge but did not show evidence of connecting that science information back to the design challenge.

Another common theme across the five cases was that even though these units were developed in order to integrate engineering into the teacher's science instruction, the explicit use of the word "engineering" was not heavily mentioned in any of the units. In one extreme case, the Mississippi River Park, the word "engineering" was never used anywhere in the unit or lesson plans. Throughout the cases, the word "design" was more commonly used when referring to engineering. The most commonly used terms as a reference to the engineering aspects of the units were "challenge" or "problem".

An important aspect of high quality STEM integration, as identified by Moore et al. ${ }^{4}$, is the opportunity for students to engage in aspects of redesign. Three of the units, Mississippi River Park, Fishermen Freezer, and Fishermen Cooker Container, provided students with the opportunity to redesign their engineering design projects. One of the units, Solar Oven, ended after the students completed their first design without including redesign. The last unit, Rocket Powered Zip Line, didn't have the students engage in or complete an engineering design challenge.

\section{Conclusions and Implications}

The five cases of STEM integration units with a focus on engineering had differing levels of focus on engineering and engineering design. While these units were a first try for the teachers involved in the study, the engineering was not as prevalent as the authors were expecting. It was not surprising to see that the content integration was primarily at the unit level and context integration was primarily at the lesson level. Since science is the primary learning objectives of the teachers, making the switch to using engineering contexts and activities has proven to be difficult for these teachers. The use of mathematics to support both the engineering and the science was generally very good among these teachers and the units they developed. Data analysis should be a support to decisions being made in both science and engineering, and the teachers and their units demonstrated this understanding.

This research brings up many more questions related to content and context integration. A limitation to this study is that it only studied the curriculum documents created by these teachers. Further study into how they implemented these units in their classrooms has the potential to shed a lot of light on some of the issues that have emerged in this study. For example, was the engineering and engineering design more or less prevalent in the classroom than it was in the lesson plans developed by the teachers? How faithful was the implementation in the classroom to the intention described in the unit plans? To what extent did content or context integration occur in the classrooms, and how does it compare to the written units? As more teachers from the professional development implement their units, these questions will be explored.

\section{Acknowledgements}

This material is based on work supported by the National Science Foundation under grant numbers NSF EEC/CAREER-1055382 and DUE-1238140. Any opinions, findings, and 
conclusions or recommendations are those of the authors and do not necessarily reflect the views of the National Science Foundation.

\section{References}

1. NGSS Lead States. (2013). Next Generation Science Standards: For States by States. Washington, DC: The National Academies Press.

2. Massachusetts Department of Education. (2009). Current curriculum frameworks: Science and technology/engineering Retrieved from http://www.doe.mass.edu/frameworks/current.html

3. Minnesota Department of Education. (2009). Minnesota academic standards: Science K-12. Retrieved from http://education.state.mn.us/MDE/EdExc/StanCurri/K-12AcademicStandards/Science/index.htm

4. Moore, T. J., Stohlmann, M. S., Wang, H.-H., Tank, K. M., Glancy, A. W., \& Roehrig, G. H. (in press). Implementation and integration of engineering in K-12 STEM education. In Ş. Purzer, J. Strobel \& M. Cardella (Eds.), Engineering in precollege settings: Research into practice. West Lafayette, IN: Purdue Press.

5. Moore, T. J. (2008). STEM integration: Crossing disciplinary borders to promote learning and engagement. Invited presentation to the faculty and graduate students of the UTeachEngineering, UTeachNatural Sciences, and STEM Education program area at University of Texas at Austin.

6. Brophy, S., Klein, S., Portsmore, M., \& Rogers, C. (2008). Advancing engineering education in P-12 classroom. Journal of Engineering Education, 97(3), 369-387.

7. Carlson, L., \& Sullivan, J. (2004). Exploiting design to inspire interest in engineering across the K-16 engineering curriculum. International Journal of Engineering Education, 20(3), 372-380.

8. Frykholm, J., \& Glasson, G. (2005). Connecting science and mathematics instruction: Pedagogical context knowledge for teachers. School Science and Mathematics, 105(3), 127-141.

9. Morrison, J. (2006). TIES STEM education monograph series, attributes of STEM education. Baltimore, MD: TIES.

10. Moore, T. J., Guzey, S. S., \& Brown, A. (in press). Greenhouse design to increase habitable land: An engineering unit. Science Scope.

11. Fortus, D., Dershimer, C., Krajcik, J., Marx, R., \& Mamlok-Naaman, R. (2004). Design-based science and student learning. Journal of Research in Science Teaching, 41(10), 1081-1110.

12. Harris, J., \& Felix, A. (2010). A project-based, STEM-integrated team challenge for elementary and middle school teachers in alternative energy. Retrieved from http://saintfrancisuniversity.edu

13. Mehalik, M. M., Doppelt, Y., \& Schunn, C. D. (2008). Middle-school science through design-based learning versus scripted inquiry: Better overall science concept learning and equity gap reduction. Journal of Engineering Education, 97(1), 71-85.

14. Smith, K. A., Sheppard, S. D., Johnson, D. W., \& Johnson, R. T. (2005). Pedagogies of engagement: Classroom-based practices. Journal of Engineering Education, 94(1), 87-100.

15. Furner, J., \& Kumar, D. (2007). The mathematics and science integration argument: A stand for teacher education. Eurasia Journal of Mathematics, Science \& Technology, 3(3), 185-189.

16. Stinson, K., Harkness, S., Meyer, H., \& Stallworth, J. (2009). Mathematics and science integration: Models and characterizations. School Science and Mathematics, 109(3), 153-161.

17. Selingo, J. (2007). Powering up the pipeline. ASEE Prism, 16(8), 24-29.

18. Dym, C. L., Agogino, A., Eris, O., Frey, D., \& Leifer, L. (2005). Engineering design thinking, teaching, and learning. Journal of Engineering Education, 94(1), 103-120.

19. National Governors Association Center for Best Practices \& the Council of Chief State School Officers. (2010). Common Core State Standards. Washington, DC: Author.

20. National Research Council. (2009). Engineering in K-12 education: Understanding the status and improving the prospects. Washington, DC: The National Academies.

21. Yin, R. K. (2003). Case study research: Design and methods (3rd ed.). Thousand Oaks, CA: Sage Publications.

22. Creswell, J. W. (2003). Research design: Qualitative, quantitative, and mixed methods approaches (2nd ed.). Thousand Oaks, CA: Sage Publications. 